\title{
RECIDIVA DE HEMANGIOMA INTRA-ORAL APÓS INTERVENÇÃO COM OLEATO DE ETANOLAMINA - ACOMPANHAMENTO DE 4 ANOS
}

Bruna de Lima PICCININ, Giselle MELO, José Miguel AMENABAR, Cleto PIAZZETA, Cassius TORRES-PEREIRA

Hemangioma é um termo utilizado freqüentemente para designar desde lesões congênitas, distúrbios de desenvolvimento até lesões de comportamento verdadeiramente neoplásico (HARRISON \& LUND, 1993). O presente estudo relata o caso de tratamento de hemangioma não congênito intra-bucal com uso de oleato de etanolamina. Paciente do sexo feminino, 7 anos de idade, leucoderma, procurou a disciplina de Estomatologia da Universidade Federal do Paraná, queixando-se de lesão no lado esquerdo da "bochecha" presente desde os 2 anos de idade. Ao exame intra-bucal observou-se a presença de um nódulo de aproximadamente $3 \mathrm{~cm}$ no maior diâmetro, localizado na mucosa jugal do lado esquerdo. O nódulo era séssil, de coloração arroxeada, superfície lisa, contornos definidos, consistência flácida, conteúdo hemorrágico com dor à palpação. Ao teste de vitropressão a lesão demonstrava abrandamento relevante da coloração inicial. O diagnóstico clínico foi de hemangioma e optou-se pelo uso de esclerose química para seu tratamento. Após duas aplicações de Oleato de Etanolamina, houve remissão quase completa do aspecto clínico inicial. Quatro anos após a esclerose a paciente retornou com queixa de recidiva lesional. Serão abordados no presente relato as características da recidiva e as opções terapêuticas adotadas ressaltando-se a necessidade de proservação pós-esclerose, particularmente em pacientes muito jovens.

Palavras chave: Odontologia; Hemangioma; Escleroterapia; 